\title{
White-Tailed Eagles' (Haliaeetus albicilla) Exposure to Anticoagulant Rodenticides and Causes of Poisoning in Poland (2018-2020)
}

\author{
Bartosz Sell *(D), Tomasz Śniegocki (1), Marta Giergiel (1) and Andrzej Posyniak
}

check for

updates

Citation: Sell, B.; Śniegocki, T.;

Giergiel, M.; Posyniak, A.

White-Tailed Eagles' (Haliaeetus

albicilla) Exposure to Anticoagulant

Rodenticides and Causes of

Poisoning in Poland (2018-2020).

Toxics 2022, 10, 63 .

https://doi.org/10.3390/

toxics10020063

Academic Editor: Manuel E.

Ortiz-Santaliestra

Received: 20 December 2021

Accepted: 29 January 2022

Published: 1 February 2022

Publisher's Note: MDPI stays neutral with regard to jurisdictional claims in published maps and institutional affiliations.

Copyright: (C) 2022 by the authors. Licensee MDPI, Basel, Switzerland. This article is an open access article distributed under the terms and conditions of the Creative Commons Attribution (CC BY) license (https:// creativecommons.org/licenses/by/ $4.0 /)$
Department of Pharmacology and Toxicology, National Veterinary Research Institute, Partyzantow 57, 24-100 Pulawy, Poland; sniego@piwet.pulawy.pl (T.Ś.); marta.giergiel@piwet.pulawy.pl (M.G.); aposyn@piwet.pulawy.pl (A.P.)

* Correspondence: bartosz.sell@piwet.pulawy.pl

\begin{abstract}
The white-tailed eagle (Haliaeetus albicilla) is strictly protected in Poland due to its threat of extinction. This study's main goal was to assess their exposure to indirect poisoning by anticoagulant rodenticides (AR). This study presents the investigation results of 40 white-tailed eagles' suspected poisoning cases in the years 2018-2020 in Poland. In all tested liver samples, using a liquid chromatography-mass spectrometry method, at least one of the AR (bromadiolone, brodifacoum, difenacoum, flocoumafen) was detected and confirmed. The other tested AR compounds (chlorophacinone, coumachlor, coumatetralyl, difethialone, diphacinone, warfarin) were not detected. The mean concentration of the sum of rodenticides was $174.4 \mu \mathrm{g} / \mathrm{kg}$ (from 2.5 to $1225.0 \mu \mathrm{g} / \mathrm{kg}$ ). In 20 cases, the sum concentration was above $100 \mu \mathrm{g} / \mathrm{kg}$ and in 10 cases it was above $200 \mu \mathrm{g} / \mathrm{kg}$. Interpretation of cases of AR poisonings should take into account their concentration in the liver, anatomopathological lesions, circumstances of death/finding of the animal, and elimination of other possible causes of poisoning. Based on this study, AR was the direct cause of death in $10 \%$ of incidents. Extensive use of rodenticides generates a high risk of poisonings of white-tailed eagles in Poland.
\end{abstract}

Keywords: anticoagulant rodenticides; poisoning; Poland; birds of prey; white-tailed eagle

\section{Introduction}

The discovery of anticoagulant rodenticides and their high efficacy significantly changed the game in the field of rodent control and led to their widespread and extensive use worldwide [1]. Their mechanism of action (inhibiting the activation of vitamin K) caused clotting disorders and gradual bleeding of animals [2,3]. The advantage of their application was a delayed toxic effect in relation to the time of poison ingestion, which eliminated the problem of learned aversion and caution of rodents regarding the introduction of new food observed with previously used poisons. First-generation anticoagulant rodenticides (FGARs) (e.g., warfarin, coumachlor) had a relatively short elimination time from the body [4]. They required several exposures to induce a toxic effect, and their extensive use tended to lead to occurrences of genetic resistance $[1,5,6]$. In the 1970s, the discovery of second-generation anticoagulant rodenticides (SGARs) (e.g., bromadiolone, brodifacoum) resulted in a significant increase in their efficacy $[3,4,7,8]$. Their potential to bioaccumulate in the body (especially in liver tissue) resulted in a longer duration of toxic action $[4,9,10]$. In many cases, a single ingestion of poison is sufficient to kill the rodents $[1,3,4,6-8,10]$. At the same time, products containing SGARs still have the character of compounds with delayed action. Unfortunately, with the increase in effectiveness, the risk of unintentionally poisoning domestic and wild animals has increased, both directly through the ingestion of the poison and indirectly by ingesting poisoned animals-especially considering the increased possibility of prey being hunted when already weakened by the poison $[1,3,4,6,11-13]$. There were observed behavioral changes in birds of prey, notable 
changes in hunting areas caused by extensive use of rodenticides in specific regions [12]. In contrast to Walter et al. [14], who suggested that the risk of indirect poisoning by brodifacoum (one of the SGARs) is minimal, we found many publications documenting cases of direct and indirect AR poisonings of wildlife $[1,4,5,8,13,15-19]$. This was based on the fact that none of the 70 labeled Norway rats was caught or removed by wild predators or scavengers [14]. The SGARs have a tendency to persist in organs containing vitamin K epoxide reductase, such as the liver, kidney, or pancreas [20]. Taking this and the available literature into account in most cases, the liver is the dedicated tissue for AR analysis [1,9,10,21-23]. In some European countries, there are organized programs to assess the occurrence of human and animal health exposures to different types of xenobiotics, including AR [19,24]. Gomez et al. [19] also pointed out the lack of data from Eastern European regions. For many years, carbofuran or other carbamate pesticides, such as aldicarb or bendiocarb, have been the most detected analytes in cases of fatal wildlife poisoning [25-28]. However, in addition to these, ARs are often also detected in birds of prey.

This research allows us to estimate the prevalence of, and assess exposure to, AR poisonings of white-tailed eagles (Haliaeetus albicilla) in Poland based on analyses of test results of 40 liver samples. For toxicological investigations, we used a previously published method that allows the analysis of compounds from the groups belonging to rodenticides, carbamate, and organophosphate pesticides, coccidiostats and mycotoxins [29].

The white-tailed eagle (Haliaeetus albicilla) is the largest predatory and scavenging freeliving species of bird in Poland, also generally widely distributed across Eurasia [30-32]. The body mass of adult individuals reaches 4 to $5 \mathrm{~kg}$, and their wingspan up to $2.5 \mathrm{~m}$ [32]. In recent decades, the population of the white-tailed eagle in Poland has shown a growing trend, which also results in a larger area of occurrence. It is most likely to nest in older forests on large trees, near feeding grounds that are rich in fish and waterbirds [30,32]. The diet of the white-tailed eagle is mainly fish, but also includes animals such as birds, mammals (including red fox Vulpes vulpes), and occasionally carrion [30,33]. This is the first report about white-tailed eagles' (Haliaeetus albicilla) exposure to AR in Poland.

\section{Materials and Methods}

\subsection{Samples Collection}

The samples were collected from dead birds across different regions of Poland, mostly from the eastern province (Figure 1), and delivered to the laboratory. Most samples were collected in the winter and delivered in a frozen state. Ten birds were fully autopsied and a further twenty were observed during sampling. In six cases, the assessment was difficult due to the partial degree of decomposition of the material provided. Some of our samples were found even several weeks after death (based on the presence of indicator parasites). Sometimes, the observation of all anatomopathological lesions was also complicated by the previously frozen state of the samples. Additional information that we were able to collect regarding anatomopathological lesions and observations of the samples received, as well as age and sex of the birds, are presented in Table S1. Samples were collected by Forest Inspectorates, Provincial Inspectorates of Environmental Protection, and private citizens. Liver samples were secured before analysis, due to the AR's predisposition to accumulate in it. After sampling, the liver samples were stored in a freezer below $-18{ }^{\circ} \mathrm{C}$. 


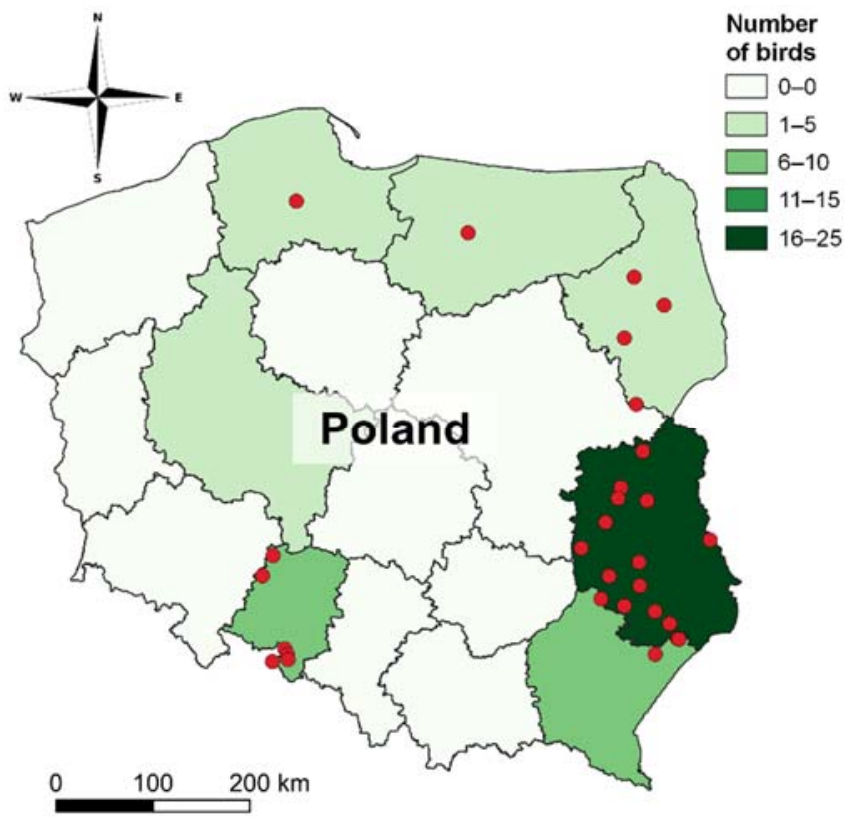

Figure 1. Sampling locations of investigated white-tiled eagles (map of sampling sites was created using QGIS software version 3.22 (QGIS.org, 2022)).

\subsection{Analytical Method}

First, the samples were scanned according to the scope of our previously described method [29], which allows detection of rodenticides (bromadiolone, brodifacoum, chlorophacinone, coumachlor, coumatetralyl, difenacoum, diphacinone, flocoumafen, warfarin, strychnine), carbamate pesticides (aldicarb, bendiocarb, carbaryl, carbofuran, dioxacarb, propoxur), organophosphorus pesticides (azinphos-ethyl, azinphos-methyl, bromophosethyl, carbophenothion, chlorfenvinphos, chlorpyrifos, diazinon, dichlofenthion, dicrotophos, dimefox, dimethoate, disulfoton, ethion, etrimfos, fonofos, malaoxon, malathion, methacrifos, methamidophos, mevinphos, omethoate, paraoxon, parathion-ethyl, parathionmethyl, phosalone, pirimiphos-ethyl, pirimiphos-methyl, propetamphos, pyrazophos, sulfotep), coccidiostats (lazalocid, maduramycin, monensin, narasin, salinomycin, semduramycin), and micotoxins (aflatoxin B1, aflatoxin B2, aflatoxin G1, aflatoxin G2, deoxynivalenol, sterygmotocystin, toxin HT-2, toxin T-2, zearalenone). Then, the list of scanned compounds was narrowed down to AR only to obtain a higher sensitivity of the method.

\subsubsection{Sample Preparation}

Liver samples were defrosted and homogenized. First, $2 \mathrm{~g}$ of sample was mixed with $5 \mathrm{~mL}$ of acetonitrile using a vortex mixer for $30 \mathrm{~s}$. Then, $0.5 \mathrm{~g}$ of sodium acetate was added and further mixed for $1 \mathrm{~min}$. The resulting suspension was sonicated for $15 \mathrm{~min}$ in an ultrasonic bath, mixed with a vortex mixer for $1 \mathrm{~min}$, and centrifuged at $2930 \times g$ rcf (relative centrifugal force). After that, $0.7 \mathrm{~mL}$ of each supernatant were added to a new centrifuge tube with $150 \mathrm{mg}$ of $\mathrm{MgSO}_{4}, 50 \mathrm{mg}$ of $\mathrm{C} 18$, and $50 \mathrm{mg}$ of Primary Secondary Amine (PSA), mixed with a vortex mixer for $1 \mathrm{~min}$, and centrifuged for $10 \mathrm{~min}$ at $2930 \times g$ rcf. The supernatant solutions were transferred to centrifuge filters $(0.2 \mu \mathrm{m})$, centrifuged at $9447 \times g$ rcf for $10 \mathrm{~min}$, and transferred to autosampler vials.

\subsubsection{Liquid Chromatography-Mass Spectrometry Analysis of AR}

Extracts from liver samples were analyzed on a Shimadzu liquid chromatography system connected to an ABSciex API 5500 Qtrap mass spectrometer. The chromatography was performed on a C8 column $(75 \mathrm{~mm} \times 2.1 \mathrm{~mm} \times 3 \mu \mathrm{m})$ with a mobile phase consisting of two solutions: $5 \%$ isopropanol in ethanol and $0.5 \%$ isopropanol in $0.1 \%$ acetic acid in water. For the AR analysis, the mass spectrometer was operating in negative ionization 
mode and the transition reactions monitored are shown in Table 1. Detailed data for the other compounds analyzed are available in Sell et al. [29].

Table 1. Transition reactions of analyzed AR monitored by mass spectrometer.

\begin{tabular}{|c|c|c|c|c|}
\hline Analyte & $\begin{array}{l}\text { Precursor Ion } \\
\text { (Da) }\end{array}$ & $\begin{array}{l}\text { Product Ions } \\
\text { (Da) }\end{array}$ & $\begin{array}{l}\text { Declustering Potential } \\
\text { (V) }\end{array}$ & $\begin{array}{l}\text { Collision Energy } \\
\text { (CE) }\end{array}$ \\
\hline Bromadiolone & 525.0 & $\begin{array}{l}181.0 \\
250.0\end{array}$ & -262 & $\begin{array}{l}-47 \\
-47\end{array}$ \\
\hline Brodifacoum & 521.1 & $\begin{array}{l}135.1 \\
143.1\end{array}$ & -120 & $\begin{array}{l}-48 \\
-80\end{array}$ \\
\hline Chlorophacinone & 373.0 & $\begin{array}{l}145.1 \\
201.2\end{array}$ & -225 & $\begin{array}{l}-33 \\
-30\end{array}$ \\
\hline Coumachlor & 340.9 & $\begin{array}{l}160.9 \\
284.0\end{array}$ & -120 & $\begin{array}{l}-30 \\
-34\end{array}$ \\
\hline Coumatetralyl & 291.7 & $\begin{array}{l}248.0 \\
142.0\end{array}$ & -270 & $\begin{array}{l}-30 \\
-40\end{array}$ \\
\hline Difenacoum & 443.0 & $\begin{array}{l}135.0 \\
143.0\end{array}$ & -254 & $\begin{array}{l}-45 \\
-75\end{array}$ \\
\hline Difethialone & 539.1 & $\begin{array}{l}151 \\
143\end{array}$ & -90 & $\begin{array}{l}-50 \\
-99\end{array}$ \\
\hline Diphacinone & 339.1 & $\begin{array}{l}116.1 \\
167.2\end{array}$ & -254 & $\begin{array}{l}-59 \\
-34\end{array}$ \\
\hline Flocoumafen & 541.2 & $\begin{array}{l}161.1 \\
382.3\end{array}$ & -205 & $\begin{array}{l}-47 \\
-35\end{array}$ \\
\hline Warfarin & 307.1 & $\begin{array}{l}161.1 \\
250.2\end{array}$ & -250 & $\begin{array}{l}-28 \\
-29\end{array}$ \\
\hline
\end{tabular}

\subsubsection{Calibration Range, Recovery, and Limit of Quantification}

The whole procedure for the determination of AR was validated according to the requirements of SANTE/11945/2015. The calibration curves were prepared for each batch by fortifying fresh blank turkey liver samples from 1.00 to $250 \mu \mathrm{g} / \mathrm{kg}$. The correlation coefficients $\left(\mathrm{R}^{2}\right)$ were between $0.98-1.00$. The average apparent recoveries for AR were in the range of $90-110 \%$, with average repeatability below $12 \%$ and average withinlaboratory reproducibility below $15 \%$. The limit of quantification (LOQ) was established at $1.00 \mu \mathrm{g} / \mathrm{kg}$ of wet liver sample for bromadiolone, brodifacoum, coumachlor, coumatetralyl, difenacoum, flocoumafen, and warfarin and $5.00 \mu \mathrm{g} / \mathrm{kg}$ for chlorophacinone, diphacinone, and difethialone. Detailed data for calibration ranges, recovery, and limit of quantification of the other analyzed compounds are available in Sell et al. [29].

\section{Results}

Between 2018 and 2020, 40 samples were collected from white-tailed eagles. In ten cases (\#2, \#4,\#13,\#15, \#19,\#20, \#29, \#30,\#34,\#36), anatomopathological lesions, observed in varying degrees of intensity, were symptomatic for blood clotting disorders and included hemorrhages, petechiae, absence of blood clots in the heart and major blood vessels, or bleeding into body cavities (Table S1). At least one AR in all analyzed liver samples were detected and two AR compounds per liver sample were found most frequently (thirty one cases). Bromadiolone was most commonly AR-detected (thirty nine cases) followed by brodifacoum (thirty eight cases), difenacoum (six cases), and flocoumafen (two cases). Chlorophacinone, coumachlor, coumatetralyl, difethialone, diphacinone, and warfarin were not detected in any analyzed samples. The mean concentration of the sum of the AR was $174.4 \mu \mathrm{g} / \mathrm{kg}$ (from 2.5 to $1225.0 \mu \mathrm{g} / \mathrm{kg}$ ). In $50 \%$ of cases, the sum of AR concentration 
was above $100 \mu \mathrm{g} / \mathrm{kg}$, and in $25 \%$ of cases it was above $200 \mu \mathrm{g} / \mathrm{kg}$. Individual data, the concentrations of AR, and their sum are presented in Table 2.

Table 2. The results of detected AR in white-tailed eagle (Haliaeetus albicilla) liver samples tested in years 2018-2020 in Poland.

\begin{tabular}{|c|c|c|c|c|c|c|}
\hline \multirow{2}{*}{ Year } & \multirow{2}{*}{ ID } & \multicolumn{5}{|c|}{ Concentration $(\mu \mathrm{g} / \mathrm{kg}$, w.w.) } \\
\hline & & Bromadiolone & Brodifacoum & Difenacoum & Flocoumafen & Sum of AR \\
\hline \multirow{13}{*}{2018} & $\# 1$ & 11.1 & 1.5 & 9.2 & 1.1 & 22.9 \\
\hline & $\# 2^{1}$ & 358.4 & 35.4 & & & 393.8 \\
\hline & \#3 & 79.5 & 14.2 & & & 93.7 \\
\hline & $\# 4^{1}$ & 53.0 & 199.3 & & & 252.3 \\
\hline & $\# 5$ & & 2.5 & & & 2.5 \\
\hline & \#6 & 2.5 & & & & 2.5 \\
\hline & $\# 7$ & 143.2 & 35.8 & & & 179.0 \\
\hline & \#8 & 78.1 & 16.4 & & & 94.5 \\
\hline & \#9 & 10.0 & 21.4 & & & 31.4 \\
\hline & $\# 10$ & 6.4 & 12.7 & & & 19.1 \\
\hline & $\# 11$ & 18.2 & 20.1 & 1.8 & & 40.1 \\
\hline & $\# 12$ & 69.0 & 172.0 & & & 241.0 \\
\hline & $\# 13^{1}$ & 170.0 & 59.6 & 7.6 & 7.6 & 244.8 \\
\hline \multirow{9}{*}{2019} & $\# 14$ & 19.4 & 61.0 & & & 80.4 \\
\hline & $\# 15^{1,2}$ & 362.0 & 53.6 & & & 415.6 \\
\hline & $\# 16$ & 57.2 & 90.6 & & & 147.8 \\
\hline & $\# 17$ & 36.7 & 68.6 & & & 105.3 \\
\hline & $\# 18$ & 83.1 & 89.1 & & & 172.2 \\
\hline & $\# 19^{1,2}$ & 88.2 & 128.2 & 3.3 & & 219.7 \\
\hline & $\# 20^{1}$ & 132.7 & 33.9 & 5.4 & & 172.0 \\
\hline & \#21 & 60.7 & 2.2 & & & 62.9 \\
\hline & $\# 22$ & 11.6 & 145.0 & & & 156.6 \\
\hline \multirow{18}{*}{2020} & $\# 23$ & 43.4 & 7.6 & & & 51.0 \\
\hline & \#24 & 25.1 & 12.9 & & & 38.0 \\
\hline & $\# 25$ & 45.5 & 16.1 & & & 61.6 \\
\hline & $\# 26$ & 38.1 & & & & 38.1 \\
\hline & \#27 & 78.1 & 56.3 & & & 134.4 \\
\hline & $\# 28$ & 12.7 & 44.8 & & & 57.5 \\
\hline & $\# 29^{1}$ & 260.0 & 27.1 & & & 287.1 \\
\hline & $\# 30^{1,2}$ & 903.0 & 19.1 & & & 922.1 \\
\hline & \#31 & 77.3 & 71.3 & & & 148.6 \\
\hline & \#32 & 72.7 & 63.3 & & & 136.0 \\
\hline & \#33 & 24.6 & 42.5 & & & 67.1 \\
\hline & $\# 34^{1,2}$ & 802.0 & 423.0 & & & 1225.0 \\
\hline & \#35 & 84.3 & 12.9 & & & 97.2 \\
\hline & $\# 36^{1}$ & 219.0 & 74.3 & & & 293.3 \\
\hline & \#37 & 95.4 & 37.5 & 10.2 & & 143.1 \\
\hline & \#38 & 31.5 & 13.6 & & & 45.1 \\
\hline & \#39 & 26.0 & 14.1 & & & 40.1 \\
\hline & $\# 40$ & 34.0 & 7.6 & & & 41.6 \\
\hline
\end{tabular}

${ }^{1}$ Birds with blood-clotting disorders; ${ }^{2}$ AR identified as the direct cause of death. 
In contrast, the levels of rodenticides are presented in Figure 2, while Table 3 shows the maximum, minimum, median, and mean concentrations in white-tailed eagle (Haliaeetus albicilla) liver samples.

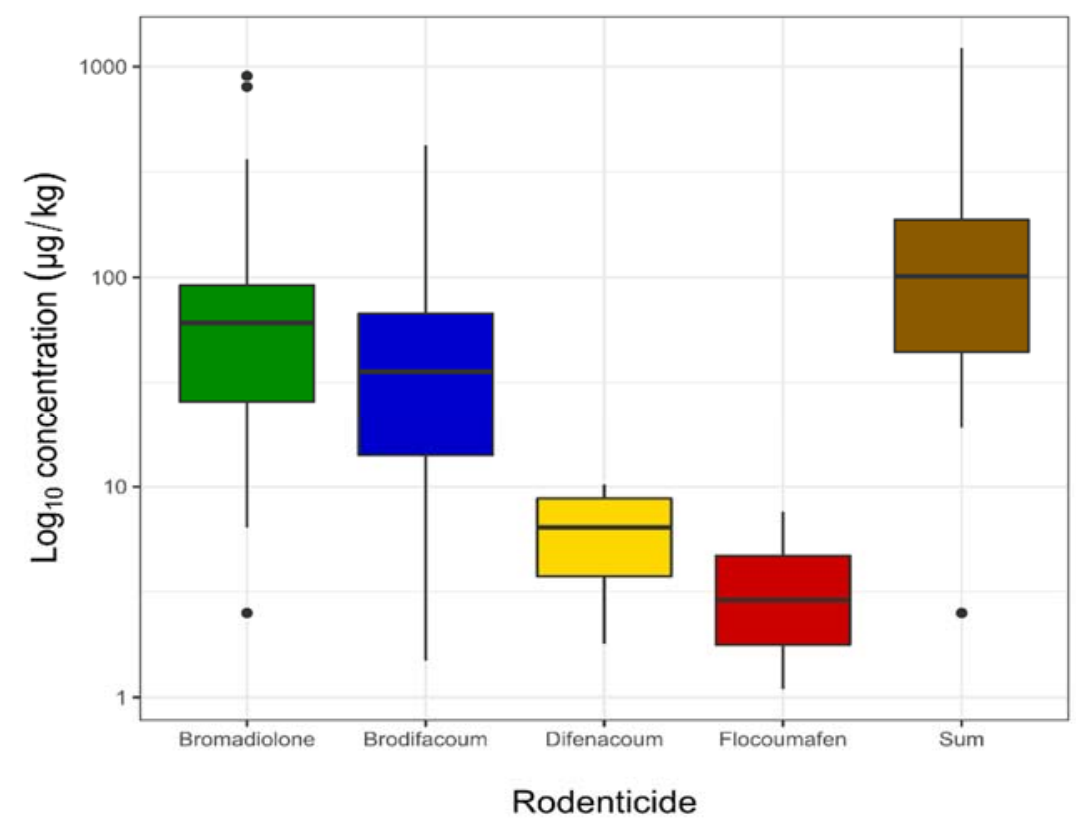

Figure 2. The levels of rodenticides found in white-tailed eagle $(n=40)$. The bold horizontal line on the graph represents the median; the box shows the interquartile range (25th-75th percentile); the whiskers show adjacent values (1.5 lengths of the interquartile range); dots indicate outliers.

Table 3. Number of cases, maximum, minimum, median, and mean value for detected AR.

\begin{tabular}{cccccc}
\hline & Bromadiolone & Brodifacoum & Difenacoum & Flocoumafen & Sum of AR \\
\hline Number of Cases & $39 / 40$ & $38 / 40$ & $6 / 40$ & $2 / 40$ & $40 / 40$ \\
\hline & & Concentration $(\mu \mathrm{g} / \mathrm{kg}$, w.w.) & \\
\hline Maximum & 903.0 & 423.0 & 10.2 & 7.6 & 1.1 \\
Minimum & 2.5 & 1.5 & 1.8 & 4.4 & 2.5 \\
Median & 60.7 & 35.6 & 6.5 & 4.4 & 101.3 \\
Mean & 121.1 & 58.1 & 6.2 &
\end{tabular}

Based on toxicological and anatomopathological investigations, AR were identified as the direct cause of death of white-tailed eagles in four cases (birds \#15, \#19, \#30, and \#34). The mean concentration of the sum of AR in these birds' livers was $695.6 \mu \mathrm{g} / \mathrm{kg}$ (from 219.7 to $1225.0 \mu \mathrm{g} / \mathrm{kg}$ ). From carbamate pesticides, in twenty-seven cases carbofuran (from 19 to $5428 \mu \mathrm{g} / \mathrm{kg}$ ) and in five bendiocarb (from 2722 to $19487 \mu \mathrm{g} / \mathrm{kg}$ ) were detected.

\section{Discussion}

The obtained results represent the first report about white-tailed eagles' (Haliaeetus albicilla) exposure to AR in Poland. If we take into consideration different species of birds of prey, the situation is similar to other countries, concluding that the main hazards from AR are SGARs, including bromadiolone and brodifacoum [1,8,11,15,18,34]. In Finland, in addition to the SGARs, coumatetralyl (the only FGAR) was detected in $48 \%$ of the samples tested; however, its measured concentrations were low, linked to its short elimination half-life and high concentration in available products [11]. In California, AR residues were detected in thirty two out of thirty eight livers tested from birds of prey [15]. Brodifacoum was found most frequently (thirty two cases), but bromadiolone (four cases) and 
difethialone (two cases) were also detected [15]. The prevalence of the AR in liver samples from predatory birds species in Denmark was 91-92\%, including SGARs [13]. If we consider the total concentration, SGARs accounted for 95\% of the burden [13]. Our results differ from Badry et al. [35] which, as a result of the analysis of 60 samples from white-tailed eagles in Germany, detected AR only in $38.3 \%$ of samples at low concentration (from 4.69 to $28.49 \mu \mathrm{g} / \mathrm{kg}$ ). In our study, bromadiolone and brodifacoum were detected in almost all tested liver samples, the prevalence of AR was 100\%, and the concentrations of AR were significantly higher (from 1.1 to $903.0 \mu \mathrm{g} / \mathrm{kg}$ ). The difference in results may also be due to the disparate ways samples were collected. Considering that the diet of white-tailed eagles consists mainly of fish and birds, and only occasionally mammals [30,33], dead or weakened rodents seem an unlikely source of AR for white-tailed eagles. Potential sources of AR for white-tailed eagles in Poland could be the red fox (Vulpes vulpes), especially during the winter period when the availability of fish is limited. The fox population in Poland is estimated at 200,000-250,000 individuals [36] and is progressively colonizing urban and suburban areas which, combined with its highly varied diet, may give it a high degree of exposure to AR. Additionally, in our experience, foxes are often targeted with bait. It was these situations in which white-tailed eagles were found near a dead fox carcass. This is usually associated with carbamates, which act quickly enough to cause the bird to fall nearby after eating the fox. Unfortunately, there is no data on the exposure of foxes to rodenticide poisoning in Poland.

Another problem we can observe in Poland is the lack of regulation and control surrounding the sale and use of particular products. For example, products containing brodifacoum and registered for professional use are freely available to anyone.

Assessing the cause of poisoning of birds of prey is often not easy, especially if we want to consider AR as a direct cause of death. Unfortunately, it is not possible to define a single threshold after which the finding would allow us to conclude AR poisoning. This is basically due to the very high variability in sensitivity to particular AR within species, races, and even within individuals or other possible situations [7]. Some authors suggest that such thresholds should be set for individual species of birds of prey, and in some publications, we can find recommended levels $>100 \mu \mathrm{g} / \mathrm{kg}$ or $>200 \mu \mathrm{g} / \mathrm{kg}$ as potentially lethal for birds of prey $[7,21]$. In our study on white-tailed eagles, we also observed signs of blood clotting disorders in many cases when the sum of AR was greater than $100 \mu \mathrm{g} / \mathrm{kg}$ (Tables 2 and S1).

We would also like to draw attention to the matter that poisoning by AR should be considered more broadly beyond concentration and anatomopathological lesions. Widespread deratization influences rodent behavior, making them easy prey for predators [12], whose primary task in ecosystems is to eliminate weak and sick individuals. By looking from the other side, we should assess the not-thoroughly-investigated impact of AR on the health and behavior of birds of prey [34]. However, some areas of AR impact are challenging to define. It is difficult to determine the long-term effects on health from exposure to even low concentrations of AR over time [34]. Even a relatively small increase in blood vessel permeability can result in bruises at a much higher rate than normal. For a predator, this type of weakness may lead to searching for an easily accessible source of food, making it even more vulnerable to indirect poisoning. Often, it can be other kinds of toxic compounds, such as fast-acting carbofuran or bendiocarb, which should always be considered when studying cases of suspected AR poisoning.

As the method used in the study allowed the detection of toxic compounds from different groups, carbofuran and bendiocarb were also detected in the analyzed samples. Carbamate pesticides, both those withdrawn from use (carbofuran) and those introduced in their place (bendiocarb), are still the main cause of poisoning in Poland. There are many documented indirect poisonings by acetylcholinesterase inhibitors $[27,28,37,38]$. In our experience, we cannot agree with Kitowski et al. [28] that detected concentrations of carbofuran in the range 11.5-237.2 $\mu \mathrm{g} / \mathrm{kg}$ can be classified as nonlethal. Due to its rapid metabolism, potential carbofuran poisoning should be considered in a much broader aspect 
than just its concentration alone in the liver, especially if we take into account the possibility of coincidence or toxic carbofuran metabolites [39].

In situations when we detect AR concentrations above 100 or $200 \mu \mathrm{g} / \mathrm{kg}$ combined with symptoms of blood-clotting disorders, another compound can be determined as the direct cause of death. For example, bird \#20 was found dead near numerous feathers of a domestic pigeon. There was a copious mucous discharge from the beak and single drops of noncoagulated blood. The anatomopathological lesions also included noncoagulated blood flowing from the severed blood vessels and heart, numerous hemorrhages, and a small amount of bloody fluid in the abdominal cavity. In the liver sample of this white-tailed eagle, the sum of AR was $172.0 \mu \mathrm{g} / \mathrm{kg}$. At first sight, it appears that the cause of death may have been AR poisoning, yet the use of the multicomponent method allowed us to detect bendiocarb at a concentration of $19,487 \mu \mathrm{g} / \mathrm{kg}$. In this case, bendiocarb was found to be the direct cause of death. Another example was white-tailed eagle \#2, where the use of a multicomponent method allowed identifying carbofuran as the direct cause of death (Table S1). The detection of carbofuran, due to its rapid action and metabolism, points to it as the primary cause of death. However, the hemorrhages and sum of AR detected at a level of $393.8 \mu \mathrm{g} / \mathrm{kg}$ pointed also to the possibility of the bird suffering an AR-induced weakness. In such cases, the detection of fast-acting and highly toxic compounds, e.g., from the carbamate group, points to them as a more probable direct cause of death. Of course, the possibility of a synergistic toxic effect of substances from both groups of compounds should also be taken into account, which would require further detailed studies.

\section{Conclusions}

White-tailed eagles had a prevalence of $100 \%$ for AR, with $50 \%$ of the eagles exceeding concentrations of $100 \mu \mathrm{g} / \mathrm{kg}$ in their livers. This demonstrates an extreme exposure in a top predator caused by an unregulated and intensive use of rodenticides in Poland. A likely source of exposure for white-tailed eagles may be the red fox, which is exposed to both indirect and intentional poisoning. AR products are very widely available and freely used without an appropriate level of monitoring. Specific regulations are needed in this field to limit the influence on wildlife health. Interpretation of toxicological test results in case of suspected AR poisoning should take into account not only the AR concentration and anatomopathological lesions, but also the circumstances of the death/finding of the animal followed by exclusion of other possible causes of poisoning, e.g., carbofuran, which in Poland is the leading cause of death of white-tailed eagles.

Supplementary Materials: The following supporting information can be downloaded at: https:/ / www.mdpi.com/article/10.3390/toxics10020063/s1, Table S1: Additional information and findings from samples of white-tailed eagles (Haliaeetus albicilla) samples tested in years 2018-2020 in Poland in cases of suspected poisonings.

Author Contributions: Conceptualization, B.S.; methodology, B.S., T.Ś. and A.P.; validation, B.S. and M.G.; formal analysis, B.S.; investigation, B.S.; resources, M.G.; data curation, B.S.; writing-original draft preparation, B.S.; writing-review and editing, B.S., T.Ś. and A.P.; visualization, T.Ś.; supervision, A.P.; project administration, B.S.; funding acquisition, B.S. All authors have read and agreed to the published version of the manuscript.

Funding: This work was the result of the implementation of research project no. 2017/25/N/NZ7/ 02409- "Exposure assessment on residues of hydroxycoumarin rodenticides in the food chain of birds of prey." funded by the National Science Centre in Poland.

Institutional Review Board Statement: Not applicable.

Informed Consent Statement: Not applicable.

Acknowledgments: We thank personnel of Forest Inspectorates, Veterinary Inspection, Provincial Inspectorates of Environmental Protection and private citizens for their contribution to the organization of the sample collection and delivery process. 
Conflicts of Interest: The authors declare no conflict of interest. The funders had no role in the design of the study; in the collection, analyses, or interpretation of data; in the writing of the manuscript, or in the decision to publish the results.

\section{References}

1. Stone, W.B.; Okoniewski, J.C.; Stedelin, J.R. Poisoning of Wildlife with Anticoagulant Rodenticides in New York. J. Wildl. Dis. 1999, 35, 187-193. [CrossRef] [PubMed]

2. Vandenbrouck, V.; Bousquet-Melou, A.; De Backer, P.; Croubels, S. Pharmacokinetics of Eight Anticoagulant Rodenticides in Mice after Single Oral Administration. J. Vet. Pharmacol. 2008, 31, 437. [CrossRef] [PubMed]

3. Erickson, W.; Urban, D. Potential Risks of Nine Rodenticides to Birds and Nontarget Mammals: A Comparative Approach. United States Environmental Protection Agency Report; Office of Pesticides Programs Environmental Fate and Effects Division: Washington, DC, USA, 2004; pp. 1-230.

4. Nakayama, S.M.M.; Morita, A.; Ikenaka, Y.; Mizukawa, H.; Ishizuka, M. A Review: Poisoning by Anticoagulant Rodenticides in Non-Target Animals Globally. J. Vet. Med. Sci. 2019, 81, 298-313. [CrossRef] [PubMed]

5. Herring, G.; Eagles-Smith, C.A.; Buck, J. Characterizing Golden Eagle Risk to Lead and Anticoagulant Rodenticide Exposure: A Review. J. Raptor Res. 2017, 51, 273-292. [CrossRef]

6. Koivisto, S.; Laakso, S.; Suomalainen, K. Literature Review on Residues of Anticoagulant Rodenticides in Non-Target Animals; TemaNord; Nordic Council of Ministers: Copenhagen, Denmark, 2010; ISBN 978-92-893-3155-5.

7. Thomas, P.J.; Mineau, P.; Shore, R.F.; Champoux, L.; Martin, P.A.; Wilson, L.K.; Fitzgerald, G.; Elliott, J.E. Second Generation Anticoagulant Rodenticides in Predatory Birds: Probabilistic Characterisation of Toxic Liver Concentrations and Implications for Predatory Bird Populations in Canada. Environ. Int. 2011, 37, 914-920. [CrossRef] [PubMed]

8. Sánchez-Barbudo, I.S.; Camarero, P.R.; Mateo, R. Primary and Secondary Poisoning by Anticoagulant Rodenticides of Non-Target Animals in Spain. Sci. Total Environ. 2012, 420, 280-288. [CrossRef] [PubMed]

9. Valverde, I.; Espín, S.; Gómez-Ramírez, P.; Navas, I.; María-Mojica, P.; Sánchez-Virosta, P.; Jiménez, P.; Torres-Chaparro, M.Y.; García-Fernández, A.J. Wildlife Poisoning: A Novel Scoring System and Review of Analytical Methods for Anticoagulant Rodenticide Determination. Ecotoxicology 2021, 30, 767-782. [CrossRef] [PubMed]

10. Fisher, P. Persistence of Four Anticoagulant Rodenticides in the Livers of Laboratory Rats. DOC Sci. Intern. Ser. 2003, 139, 18.

11. Koivisto, E.; Santangeli, A.; Koivisto, P.; Korkolainen, T.; Vuorisalo, T.; Hanski, I.K.; Loivamaa, I.; Koivisto, S. The Prevalence and Correlates of Anticoagulant Rodenticide Exposure in Non-Target Predators and Scavengers in Finland. Sci. Total Environ. 2018, 642, 701-707. [CrossRef]

12. Vyas, N.B.; Kuncir, F.; Clinton, C.C. Influence of Poisoned Prey on Foraging Behavior of Ferruginous Hawks. Am. Midl. Nat. 2017, 177, 75-83. [CrossRef]

13. Christensen, T.K.; Lassen, P.; Elmeros, M. High Exposure Rates of Anticoagulant Rodenticides in Predatory Bird Species in Intensively Managed Landscapes in Denmark. Arch Env. Contam Toxicol 2012, 63, 437-444. [CrossRef] [PubMed]

14. Walther, B.; Ennen, H.; Geduhn, A.; Schlötelburg, A.; Klemann, N.; Endepols, S.; Schenke, D.; Jacob, J. Effects of Anticoagulant Rodenticide Poisoning on Spatial Behavior of Farm Dwelling Norway Rats. Sci. Total Environ. 2021, 787, 147520. [CrossRef] [PubMed]

15. Kelly, T.R.; Poppenga, R.H.; Woods, L.A.; Hernandez, Y.Z.; Boyce, W.M.; Samaniego, F.J.; Torres, S.G.; Johnson, C.K. Causes of Mortality and Unintentional Poisoning in Predatory and Scavenging Birds in California. Vet. Rec. Open 2014, 1, e000028. [CrossRef] [PubMed]

16. Joermann, G. A Review of Secondary-Poisoning Studies with Rodenticides. EPPO Bull. 1998, 28, 157-176. [CrossRef]

17. Hydock, K.L.; DeClementi, C.; Fish, P.H. Second-Generation Anticoagulant Rodenticide Poisoning in a Captive Andean Condor (Vultur Gryphus). J. Avian Med. Surg. 2017, 31, 256-261. [CrossRef] [PubMed]

18. Lohr, M.T. Anticoagulant Rodenticide Exposure in an Australian Predatory Bird Increases with Proximity to Developed Habitat. Sci. Total Environ. 2018, 643, 134-144. [CrossRef] [PubMed]

19. Gómez-Ramírez, P.; Shore, R.F.; van den Brink, N.W.; van Hattum, B.; Bustnes, J.O.; Duke, G.; Fritsch, C.; García-Fernández, A.J.; Helander, B.O.; Jaspers, V.; et al. An Overview of Existing Raptor Contaminant Monitoring Activities in Europe. Environ. Int. 2014, 67, 12-21. [CrossRef] [PubMed]

20. Eason, C.T.; Murphy, E.C.; Wright, G.R.G.; Spurr, E.B. Assessment of Risks of Brodifacoum to Non-Target Birds and Mammals in New Zealand. Ecotoxicology 2002, 11, 35-48. [CrossRef] [PubMed]

21. Berny, P.J.; Buronfosse, T.; Buronfosse, F.; Lamarque, F.; Lorgue, G. Field Evidence of Secondary Poisoning of Foxes (Vulpes Vulpes) and Buzzards (Buteo Buteo) by Bromadiolone, a 4-Year Survey. Chemosphere 1997, 35, 1817-1829. [CrossRef]

22. Howald, G.R.; Mineau, P.; Elliott, J.E.; Cheng, K.M. Brodifacoum Poisoning of Avian Scavengers During Rat Control on a Seabird Colony. Ecotoxicology 1999, 8, 431-447. [CrossRef]

23. Stone, W.B.; Okoniewski, J.C.; Stedelin, J.R. Anticoagulant Rodenticides and Raptors: Recent Findings from New York, $1998-2001$. Bull. Environ. Contam. Toxicol. 2003, 70, 0034-0040. [CrossRef] [PubMed]

24. Dulsat-Masvidal, M.; Lourenço, R.; Lacorte, S.; D'Amico, M.; Albayrak, T.; Andevski, J.; Aradis, A.; Baltag, E.; Berger-Tal, O.; Berny, P.; et al. A Review of Constraints and Solutions for Collecting Raptor Samples and Contextual Data for a European Raptor Biomonitoring Facility. Sci. Total Environ. 2021, 793, 148599. [CrossRef] [PubMed] 
25. Rial-Berriel, C.; Acosta-Dacal, A.; Zumbado, M.; Henríquez-Hernández, L.A.; Rodríguez-Hernández, Á.; Macías-Montes, A.; Boada, L.D.; Travieso-Aja, M.d.M.; Martin-Cruz, B.; Suárez-Pérez, A.; et al. Epidemiology of Animal Poisonings in the Canary Islands (Spain) during the Period 2014-2021. Toxics 2021, 9, 267. [CrossRef] [PubMed]

26. González, L.M.; Margalida, A.; Mañosa, S.; Sánchez, R.; Oria, J.; Molina, J.I.; Caldera, J.; Aranda, A.; Prada, L. Causes and Spatio-Temporal Variations of Non-Natural Mortality in the Vulnerable Spanish Imperial Eagle Aquila Adalberti during a Recovery Period. Oryx 2007, 41, 495-502. [CrossRef]

27. Wobeser, G.; Bollinger, T.; Leighton, F.A.; Blakley, B.; Mineau, P. Secondary Poisoning of Eagles Following Intentional Poisoning of Coyotes with Anticholinesterase Pesticides in Western Canada. J. Wildl. Dis. 2004, 40, 163-172. [CrossRef] [PubMed]

28. Kitowski, I.; Łopucki, R.; Stachniuk, A.; Fornal, E. A Pesticide Banned in the European Union over a Decade Ago Is Still Present in Raptors in Poland. Environ. Conserv. 2020, 47, 310-314. [CrossRef]

29. Sell, B.; Sniegocki, T.; Zmudzki, J.; Posyniak, A. Development of an Analytical Procedure for the Determination of Multiclass Compounds for Forensic Veterinary Toxicology. J. Anal. Toxicol. 2018, 42, 183-191. [CrossRef] [PubMed]

30. Olszewski, A.; Matusiak, J.; Sea-eagle, W. Breeding biology and ecology of the White-tailed Sea-eagle Haliaeetus albicilla in the Kampinos National Park. Kulon 2020, 25, 69-91.

31. Wardecki, Ł.; Chodkiewicz, T.; Beuch, S.; Smyk, B.; Sikora, A.; Neubauer, G.; Meissner, W.; Marchowski, D.; Wylegała, P.; Chylarecki, P. Monitoring Ptaków Polski w latach 2018-2021. Biul. Monit. Przyr. 2021, 22, 1-80.

32. Zawadzki, G.; Zawadzka, D.; Sołtys, A.; Drozdowski, S. Nest-Site Selection by the White-Tailed Eagle and Black StorkImplications for Conservation Practice. For. Ecosyst. 2020, 7, 59. [CrossRef]

33. Ekblad, C.; Tikkanen, H.; Sulkava, S.; Laaksonen, T. Diet and Breeding Habitat Preferences of White-Tailed Eagles in a Northern Inland Environment. Polar Biol 2020, 43, 2071-2084. [CrossRef]

34. Rached, A.; Moriceau, M.-A.; Serfaty, X.; Lefebvre, S.; Lattard, V. Biomarkers Potency to Monitor Non-Target Fauna Poisoning by Anticoagulant Rodenticides. Front. Vet. Sci. 2020, 7, 616276. [CrossRef] [PubMed]

35. Badry, A.; Schenke, D.; Treu, G.; Krone, O. Linking Landscape Composition and Biological Factors with Exposure Levels of Rodenticides and Agrochemicals in Avian Apex Predators from Germany. Environ. Res. 2021, 193, 110602. [CrossRef] [PubMed]

36. Tylkowska, A.; Pilarczyk, B.; Tomza-Marciniak, A.; Pilarczyk, R. The Prevalence of Intestinal Nematodes among Red Foxes (Vulpes Vulpes) in North-Western Poland. Acta Vet. Scand. 2021, 63, 19. [CrossRef] [PubMed]

37. Berny, P. Pesticides and the Intoxication of Wild Animals. J. Vet. Pharmacol. Ther. 2007, 30, 93-100. [CrossRef] [PubMed]

38. Guitart, R.; Sachana, M.; Caloni, F.; Croubels, S.; Vandenbroucke, V.; Berny, P. Animal Poisoning in Europe. Part 3: Wildlife. Vet. J. 2010, 183, 260-265. [CrossRef] [PubMed]

39. Gupta, R.C. Carbofuran Toxicity. J. Toxicol. Environ. Health 1994, 43, 383-418. [CrossRef] 